\title{
POTENTIAL OF TRANSFORMATIONS IN POLYCODE INTERNET MEME WITHIN THE EVENT-RELATED CONTEXT OF $2020^{1}$
}

Submitted: 09.11.2020

Accepted: 12.01.2021

\author{
Oxana S. Issers \\ Dostoevsky Omsk State University, Omsk, Russia
}

\begin{abstract}
The article deals with a specific polycode text that functions in the field of virtual communication Internet meme. The focus is on its regular transformations. Considering possible methodological approaches to the analysis of this phenomenon, the author comes to the conclusion about the efficiency of using the methodology of intertext linguistic theory. The essential characteristic of a meme is its transformational potential, which allows to create new meanings and use this communication unit in a wide range of relevant contexts. The polycode structure of a meme determines the spectrum of its potential transformations by changing the verbal and visual elements. The material of observations was one of the most popular memes of 2020 - "Get up, Natasha, we dropped everything". The author identifies 8 meme transformations, which can be considered as regular: development of the visuals with the addition of a verbal element; contraction of the visuals with the same verbal element / transformation of the verbal element; the reframing of the context; pragmatic transformation; intertextual transformation, including the effect of meta-communication; reduction of the image with the same visual markers; reframing with the change of verbal and visual elements; adaptation of the meme in the media texts. The latter transformation indicates the successful inclusion of the Internet meme as a communication element of network coverse in modern discursive practices.
\end{abstract}

Key words: Internet meme, polycode text, meme 2020, media text, intertext, text transformations.

Citation. Issers O.S. Potential of Transformations in Polycode Internet Meme Within the Event-Related Context of 2020. Vestnik Volgogradskogo gosudarstvennogo universiteta. Seriya 2. Yazykoznanie [Science Journal of Volgograd State University. Linguistics], 2021, vol. 20, no. 2, pp. 26-41. (in Russian). DOI: https://doi.org/ 10.15688/jvolsu2.2021.2.3

УДК 81 '42:004.738.5

Дата поступления статьи: 09.11.2020

ББК 81.055 .51 .1 Дата принятия статьи: 12.01.2021

\section{ПОТЕНЦИАЛ ТРАНСФОРМАЦИЙ ПОЛИКОДОВОГО ИНТЕРНЕТ-МЕМА В СОБЫТИЙНОМ КОНТЕКСТЕ 2020 ГОДА ${ }^{1}$}

\author{
Оксана Сергеевна Иссерс \\ Омский государственный университет им. Ф.М. Достоевского, г. Омск, Россия
}

\begin{abstract}
Аннотация. Статья посвящена специфическому поликодовому тексту, функционирующему в сфере виртуальной коммуникации, - интернет-мему. В фокусе внимания находятся его регулярные трансформации. Рассматривая возможные методологические подходы к анализу данного феномена, автор приходит к выводу о продуктивности использования методологии лингвистической теории интертекста. Сущностным свойством мема является его трансформационный потенциал, который позволяет создавать новые смыслы ত̄ и использовать эту коммуникационную единицу в широком спектре актуальных контекстов. Поликодовая структура мема определяет спектр его потенциальных трансформаций посредством изменения вербального и визуального компонентов. Материалом наблюдений стал один из популярных мемов 2020 года - «Вставай, Наташа, мы все уронили». Автор выделяет 8 трансформаций мема, которые можно рассматривать как регуло лярные: развертывание визуального ряда с добавлением вербального компонента; свертку визуального ряда с сохранением / трансформацией вербального компонента; рефрейминг контекста; прагматическую транс() формацию; интертекстуальную трансформацию, в том числе с эффектом метакоммуникации; редукцию
\end{abstract}


изображения с сохранением визуальных маркеров; рефрейминг с изменением вербального и визуального компонентов; адаптацию мема в медиатекстах, которая указывает на успешное включение интернет-мема как коммуникационного элемента сетевого общения в современные дискурсивные практики.

Ключевые слова: интернет-мем, поликодовый текст, мем 2020 года, медиатекст, интертекст, трансформации текста.

Цитирование. Иссерс О. С. Потенциал трансформаций поликодового интернет-мема в событийном контексте 2020 года // Вестник Волгоградского государственного университета. Серия 2, Языкознание. 2021. - T. 20, № 2. - C. 26-41. - DOI: https://doi.org/10.15688/jvolsu2.2021.2.3

\section{Введение}

Разные периоды социальной жизни оставляют неодинаковый след в развитии языка. История может отразиться в языковом сознании как период бурных языковых изменений или относительного затишья. Те временные срезы, которые оказывают длительное и мощное воздействие на развитие языка и коммуникационных процессов, представляются наиболее привлекательными для научного осмысления. Разумеется, большое видится на расстоянии и должно пройти время, чтобы можно было с научной точки зрения оценить происшедшие изменения. Однако для этого требуется своевременно зафиксировать новации в непосредственном наблюдении.

Такой социолингвистический подход стал особенно востребован, когда в России вслед за западными проектами стали реализовываться аналогичные проекты «Слово года». Точная хронологическая фиксация вхождения в язык тех или иных лексических единиц не единственная их задача. Важно и то, что в процессах развития языка отражается общественная оценка событий и явлений, которые были в фокусе общественного внимания в конкретный период. Эти наблюдения и исследования представляют междисциплинарный интерес - как для лингвистов, так и для политологов, социологов, социальных психологов, культурологов.

2020 год, без сомнения, стал более ярким в дискурсивном отношении, чем предшествующие. Коронавирус и охватившая мир пандеми́я оставили в языке не только лексический след - это широкая область для лингвистического анализа представлена целым рядом публикаций (см., например, тематический выпуск научного журнала «Коммуникативные исследования» № 3 за 2020 г.). События 2020 г. отразились в многочисленных мемах, которые с мгновенной скоростью, доступной новейшим коммуникационным технологиям, распространились к интернет-пространстве и породили бесчисленные трансформации. Например, одним из самых популярных мемов года стала картинка про Наташу и котов, которые «все уронили»: по запросу «Наташа, вставай» Google выдает более полумиллиона ссылок только на картинки.

Мемы, характеризующие определенный период, представляют интерес и как специфическая реакция сетевого сообщества на социально-экономические стимулы, и как коммуникационный феномен, в основе которого лежат процессы репликации и генерации новых смыслов посредством вербального и визуального кодов. Для осмысления этого феномена массовой культуры требуется обозначить исходные методологические позиции.

\section{Материал и методы}

\section{Между теорией интертекста и меметикой: в поисках методологической базы}

На современном этапе развития лингвистики и смежных гуманитарных наук деривационные процессы в языке привлекают повышенное внимание исследователей. На волне «постмодернистской революции», которая произошла в филологии в 70-е гг. ХХ в., весь процесс коммуникации стали рассматривать как проекции и ссылки одного текста на другой, поскольку все вместе они являются частью «всеобщего Текста» [Барт, 1989]. Динамическая модель отношений языковых объектов, в которых текст предстает как «генератор смыслов», объясняет многие механизмы смыслопорождения. Этот подход стал отправной точкой теории интертекстуальности, оформившейся в последней четверти XX века. 


\section{ТЕОРЕТИЧЕСКИЕ ПРОБЛЕМЫ ИССЛЕДОВАНИЯ ТЕКСТОВ}

«Каждый текст является интертекстом; другие тексты присутствуют в нем на разных уровнях в более или менее узнаваемых формах: тексты предшествующей культуры и тексты окружающей культуры. Каждый текст представляет собой новую ткань, сотканную из старых цитат» [Барт, 1989, с. 388].

Западные идеи постструктурализма и постмодернизма (Ж. Дерида, М. Фуко, Р. Барт, Ж. Лакан, Ю. Кристева и др.) во многом опирались на отечественную лингвистическую традицию. В частности, новый термин - интертекст - был введен в научный оборот в 1967 г. Ю. Кристевой в работе, посвященной анализу статьи М.М. Бахтина «Проблемы содержания, материала и формы в словесном художественном творчестве», написанной более 40 лет назад, в 1924 г. [Кристева, 2000]. По логике М.М. Бахтина, любое высказывание является звеном в цепи и вне этой цепи не может быть изучено [Бахтин, 1979, с. 340], «каждое слово пахнет контекстом и контекстами, в которых оно жило» [Бахтин, 1975, c. 106]. Данный подход обусловливает интерес к трансформациям текста, его деривационной истории, которая не может быть осмыслена вне процессов коммуникации.

Лингвистическая теория Б.М. Гаспарова, открывшая новое направление в изучении взаимосвязей и взаимовлияний текстов (несмотря на то, что автор предпочитает обходиться без термина интертекст), базируется и на теории М.М. Бахтина, и на концепции постмодернистов о тексте как цитатной мозаике: «наша языковая деятельность осуществляется как непрерывный поток “цитации”, черпаемой из конгломерата нашей языковой памяти» [Гаспаров, 1996, с. 14]. Особенностью языковой памяти является хранение в ней «коммуникативных фрагментов»- отрезков речи различной длины, которыми говорящий оперирует как готовыми блоками («стационарными частицами его языкового опыта») при создании и интерпретации высказываний. По мнению ученого, эти фрагменты обладают смысловой слитностью, коммуникативной заряженностью (способностью направлять течение коммуникации) и пластичностью [Гаспаров, 1996, с. 122].

Для нашего исследования актуально представление Б.М. Гаспарова о том, что в про- цессе языковой деятельности говорящие как бы погружаются в окружающее их коммуникативное пространство, где черпают прототипические образы, ситуации в их жанровом и эмоциональном своеобразии, аналогии или находят прямые отсылки к прошлому языковому опыту (см. об этом: [Кузьмина, 1999, с. 17]).

Проецируя идеи Б.М. Гаспарова на генерацию и развитие интернет-мемов, можно рассматривать этот феномен именно как активизацию «коммуникативных фрагментов», которые выполняют аналогичную функцию. Их трансформационный потенциал обусловлен способностью адаптироваться к новым условиям («коммуникационная заряженность» и «пластичность», по Б.М. Гаспарову), работать «здесь и сейчас» над созданием новых смыслов. Механизм порождения нового смысла объясняется структурой коммуникативного фрагмента: он включает смысловое ядро и периферию, обладающую «рыхлой семантикой». Эта особенность структуры позволяет создавать пластичные переходы от одного ядра к другому: «рыхлость границ фрагмента, способность его пластично изменять очертания (выделено нами. - О. И.) создает предпосылку для тех срастаний и растворений, которые происходят с ним в высказывании» [Гаспаров, 1996, с. 128].

Несмотря на то что концепция Б.М. Гаспарова ориентирована на коммуникативное пространство вербального текста, она вполне приложима и к текстам неоднородной семиотической структуры, в частности поликодовым. Преобразование вербальных и визуальных составляющих смыслового ядра, а также эмоционально-оценочных компонентов прототекста позволяет осуществить его разнообразные трансформации, изменить основные мотивы, с которыми установлены интертекстуальные связи, и генерировать новые смыслы.

Идеи интертекстуальности, сформировавшие теорию интертекста как самостоятельное научное направление, были высказаны примерно одновременно с концепциями меметики - в 70-х гг. прошлого века. Однако их существенное различие связано с методологическими установками. Если первое направление развивалось и развивается в рамках антропоцентризма и в качестве исходной посылки рассматривает культуру и коммуни- 
кацию как сферу реализации креативной способности человека, то меметика сформировалась на базе эволюционной теории (в особенности популяционной генетики), проецируя биологические концепции на человеческую культуру.

В 1976 г. в книге «Эгоистичный ген» биолог Р. Докинз определил мим ${ }^{2}$ (от древнегреч. $\mu л \mu \eta \tau \dot{\eta}$ - «имитатор», «подражатель») как своеобразный аналог понятия гена в генетике, единицу передачи культурного наследия, способную к репликации: «Точно так же, как гены распространяются в генофонде, переходя из одного тела в другое с помощью сперматозоидов или яйцеклеток, мимы распространяются в том же смысле, переходя из одного мозга в другой с помощью процесса, который в широком смысле можно назвать имитацией» [Докинз, 1993, с. 173]. По Докинзу, мем есть своего рода культурная универсалия и, таким образом, он является основным механизмом трансляции культурного наследия.

Вслед за Р. Докинзом, феномен спонтанной репликации единиц текстовой и визуальной информации привлек внимание американского когнитивиста Д. Хофштадтера, который также определил это понятие по сходству с биологическими процессами: как и в развитии живых существ, эволюция культуры рассматривается им как процесс создания дочерних структур на основе родительской «молекулы» (от лат. replicatio - «возобновление») [Hofstadter, 1996].

Однако с начала 2000-х гг. наблюдается формирование критического отношения к концепции меметики и самому ее статусу как научной дисциплины. Критики идеи «дарвинизации культуры» не считают обоснованным перенесение принципов генетики на анализ информационных процессов в других сферах. Так, Луис Бенитес Брибьеска, медик-исследователь из Мексики, определил меметику как «опасную идею»: по его мнению, она представляет «угрозу серьезным исследованиям проблем сознания и культурной эволюции», поскольку механизм мутации мемов достаточно непредсказуем, вносит хаос в эволюционный процесс [Benítez Bribiesca, 2001].

По мнению А. Ашкерова, вся «научность» меметики была и остается на уровне яркой остроумной аналогии с «генами-репликаторами»: «Меметика навсегда застряла на уровне блестящего, публицистически броского сравнения ген-мем-вирус, эксплуатируя при этом все таящиеся в обществе подспудные страхи и опасения по поводу возможности манипуляции сознанием научными методами» (цит. по: [Савицкая, 2013]). Доказательством методологической неопределенности научной концепции стало прекращение выпуска издания «Journal of Memetics» в 2005 г. с публикацией в последнем номере статьи Брюса Эдмондса, подводящей неутешительный итог научных поисков апологетов меметики [Edmonds, 2005].

Перспективы возрождения меметики и междисциплинарного изучения интернетмемов, на наш взгляд, намечены И. Вершининым. По его мнению, «меметика может получить новую жизнь, если будет четкий объект изучения, который можно наблюдать, измерить и подвергать воздействию» [Вершинин].

Таким образом, методология лингвистической теории интертекста, на наш взгляд, в гораздо большей степени отвечает задачам изучения структур, называемых мемами, чем меметика, впервые избравшая их в качестве объекта научного изучения. «Коммуникационная заряженность» и «пластичность», по Гаспарову, определяют сущностное свойство мема - его трансформационный потенциал. Последний же создает возможности для генерации новых смыслов, адаптации к новым коммуникативным задачам и функционирования в разнообразных типах текстов.

\section{От смешного до серьезного: в поисках функции}

Тупиковая ситуация с меметикой как научной концепцией не повлияла ни на существование самого феномена мема, ни на утрату исследовательского интереса к нему. Напротив, с бурным развитием в середине 2000-х гг. интернет-коммуникаций, с их ускоренными в сотни раз возможностями передачи информации внимание к феномену мема, его функционированию в медиапространстве и трансформационному потенциалу только усилилось. 


\section{ТЕОРЕТИЧЕСКИЕ ПРОБЛЕМЫ ИССЛЕДОВАНИЯ ТЕКСТОВ}

Как считают исследователи, в современной коммуникации функция мемов обусловлена их влиянием на массовое сознание. Мемы стали «мощным, хотя и скрытым фактором формирования общественного мнения и шире - современной ментальности; иначе говоря, социально-культурным явлением, с которым нельзя не считаться» [Савицкая, 2013].

Т.Е. Савицкая полагает, что на стадии зарождения мем выполняет функцию группового идентификатора («субкультурного маркера»), поскольку для его понимания требуется знание конкретного культурного контекста: «мем формирует демаркационную линию между «своими» и «чужими». Эффект распространения мема в медиапространстве также в большинстве случаев объясняется потребностью в культурно-групповой идентификации. Исследователь акцентирует внимание на том, что «в свободном коммуникативном пространстве интернета успешный мем быстро вырывается из "субкультурного гетто" и "растекается по блогосфере"... Такой мем-клише, речевой или визуальный штамп, по сути, превращается в информационный вирус» [Савицкая, 2013].

Рассматривая интернет-мем в аспекте его юмористического потенциала, Ю.В. Щурина отмечает, что возможность групповой идентификации обусловлена общей когнитивной базой - знанием прецедентного феномена: «Эффективность коммуникации в этом случае прямо зависит от умения интернетпользователя осуществить экспликацию скрытых культурных коннотаций мема, восстановить те ассоциативные связи, которыми обеспечен комический эффект» [Щурина, 2012, c. 163].

В этом же направлении выстраивает свои размышления И.В. Ксенофонтова. Анализируя стереотипные комментарии в блогах, она приходит к выводу: «Человек просто ставит в комментарии культурный код, предъявляя реципиентам сразу два сообщения: “я - свой” и свое закодированное отношение. Знание мемов считается в каком-то смысле необходимым для “выживания” в культурном пространстве» [Ксенофонтова, 2009, с. 287].

Другая функция интернет-мема, не противоречащая названной выше, связана с его развлекательной, игровой направлен- ностью. По мнению А.А. Сычева, она способствует актуализации в Сети смеховой стихии [Сычев].

Однако этим не ограничивается функциональная нагруженность текстов-мемов. «Почему же мем оказался столь успешным преемником анекдота в его роли орудия активизации общественного самосознания и гражданской активности?» - задается вопросом Т.Е. Савицкая, тем самым намечая еще одну не менее актуальную функцию интернетмема. Мем становится не только идентифицирующим культурным кодом, но и транслятором общественно значимых идей, идеологической позиции, что позволяет рассматривать эти тексты как инструменты в различных типах коммуникации, в том числе и политической. Именно в этой функции они проникают в медиатексты и воспринимаются адресатом как сигнал отнюдь не развлекательного дискурса.

Кроме того, арсенал актуальных мемов активно используется в качестве инструмента маркетинга, рекламы и PR. Как отмечает Е.М. Забалуева, мемы находят применение в маркетинговых стратегиях компаний, осуществляющих свою деятельность в самых различных сферах - коммерческой, туристической, финансовой и др. [Забалуева, 2018, с. 280].

Задача нашего исследования - проследить возможные трансформации поликодового мема, содержащего вербальный и визуальный компоненты, с момента зарождения до вхождения в медиатексты, с учетом изменений его плана выражения и плана содержания. В качестве материала исследования использован мем, вошедший в ТОП мемов 2020 г., Вставай, Наташа. Мы все уронили, в его разнообразных трансформациях, бытующих в медиапространстве.

Трансформации мемов разной семиотической природы не раз попадали в поле исследовательского интереса. Это неслучайно: специфика мема как элемента современной массовой культуры как раз и заключается в том, что он, по мнению К. Турковой, «всегда точно характеризует какую-то конкретную историю и в то же время оказывается применим к другим частным ситуациям... $<\ldots>$ Непредсказуемость и спонтанность распространения "вируса" можно считать самой инте- 
ресной составляющей мема» (Как устроена...). Именно эти свойства Б.М. Гаспаров называл «коммуникационной заряженностью» и «пластичностью» (см. об этом выше).

Е.А. Нежура отмечает, что эксперименты с креолизованными текстами, в том числе мемами, являются типичными для виртуального общения, при этом наблюдается как появление новых знаков поликодовой природы, так и вторичный семиозис уже имеющихся языковых и неязыковых единиц [Нежура, 2012]. В частности, одной из популярных трансформаций визуального образа (фото или картинки) является так называемая «фотожаба» - изменение исходного изображения при помощи графического редактора [Щурина, 2012]. Ю.В. Щурина рассматривает возможности лексической и графической трансформации «медиамемов» - комических видеосюжетов, которые могут обретать новые интерпретации. Среди поликодовых комических интернет-жанров автор выделяет эдвайсы и демотиваторы: при сохранении визуального образа-рамки они активно трансформируются за счет вербальной составляющей текста [Шурина, 2013].

Однако при неослабевающем внимании к феномену мема его трансформационный потенциал и последовательность деривационных этапов еще не стали объектом пристального внимания исследователей.

Хронологическая привязка к конкретному периоду (2020 г.) позволяет продемонстрировать реальные трансформации конкретного мема на уровне формы и содержания в неразрывной и закономерной связи с социокультурным и общественно-политическим контекстом.

\section{Результаты и обсуждение}

\section{Трансформации интернет-мемов в событийном контексте 2020 года}

Ушедший год, без сомнения, оставил неизгладимый след во всех сферах социальнополитической жизни планеты. В первую очередь это связано с глобальным событием пандемией, охватившей все без исключения страны в первые месяцы 2020 года. Кроме новостей о распространении коронавирусной инфекции, не менее значимыми для российского общества были сообщения об обвале рубля и обнулении президентских сроков.

Запоминающимся этот год стал и в лингвистическом смысле - как в России, так и за рубежом. В частности, пополнился новообразованиями лексический фонд (ковид, "корона», ковидодиссиденты, масочноперчаточный режим, антительный (о людях) и др.), трансформировались такие концепты, как самоизоляция, социальная дистанция и т. д. В общественном сознании выкристаллизовались новые символы Добра и Зла: на одном полюсе - врачи, медики, дистаниионное / гибридное обучение, маски, на другом - летучие мылии, прогулки, шашль$\kappa и$ (в период первомайских праздников, по мнению эпидемиологов, они способствовали распространению инфекции). Призыв Не общайтесь с пожилыми родителями! никогда ранее не звучал так позитивно в контексте социальной ответственности. Новые явления в языке и коммуникации сразу же попали в поле лингвистического наблюдения [Балашова, 2020; Зайцева, 2020; Куссе, 2020; Радбиль, 2020; Савченко, Лай Янь-Цзюнь, 2020; Северская, 2020; и др.]. Преимущественно дистантные технологии коммуникации в образовательной и деловой сферах сформировали соответствующие сетевые практики общения [Кронгауз, 2020].

На фоне многообразных языковых и дискурсивных новаций, актуальных для 2020 г., интернет-мемы также являются репрезентативным материалом для воссоздания «коммуникативного ландшафта» одного года (в терминологии Х. Куссе), помогают понять, как в общественном сознании отразились события рассматриваемого периода.

На рисунке 1 представлен топ-20 мемов, которые, по данным компьютерной базы СМИ «Медиалогия», чаще всего использовало сетевое сообщество в 2020 г. (Лучшие мемы...). Количество сообщений с этими «знаками текущего момента» исчисляется десятками и сотнями тысяч.

Одним из самых популярных в первом полугодии 2020 г. стал шестипанельный комикс с несколькими котами. Они как бы обращаются к хозяйке и говорят: «Наташ, мы все уронили. Мы уронили вообще все, честно» (см. рис. 2). 


\section{ТЕОРЕТИЧЕСКИЕ ПРОБЛЕМЫ ИССЛЕДОВАНИЯ ТЕКСТОВ}

\section{TOП-20 MЕMOB B СОЦСЕТЯХ ЗА 2020 ГОД}

\section{Обнуление}

5377,9

Билл Гейтс и Чипирование

AYФ

521,5

Печенеги и половцы

419,9

Наташа, мы всё уронили

305,7

Вы не понимаете, зто другое

257,5

Безумно мохко быть первым

252,0

Ведьмаку заплатите чеканной монетой $\quad 230,7$

Плачу на техно

228,7

2020, уходи

Загадка от Жака Фреско

163,2

160,6

Гуччи флип флапс

141,2

Природа настолько очистилась $\quad 109,6$

$\begin{array}{ll}\text { Батут работает } & 107,7\end{array}$

Танцующие носильщики гробов $\quad 104,9$

$\begin{array}{ll}\text { Коля Лукашенко } & \mathbf{8 6 , 7}\end{array}$

Просто здравствуй, просто как дела $\quad$ 73,4

Bот это папапаповорот $\quad$ 45,2

Расчленинград $\quad 38,8$

Данные по сомиальн

Рис. 1. Топ-20 мемов в соцсетях за 2020 г.

Fig. 1. Top 20 memes in social networks for 2020
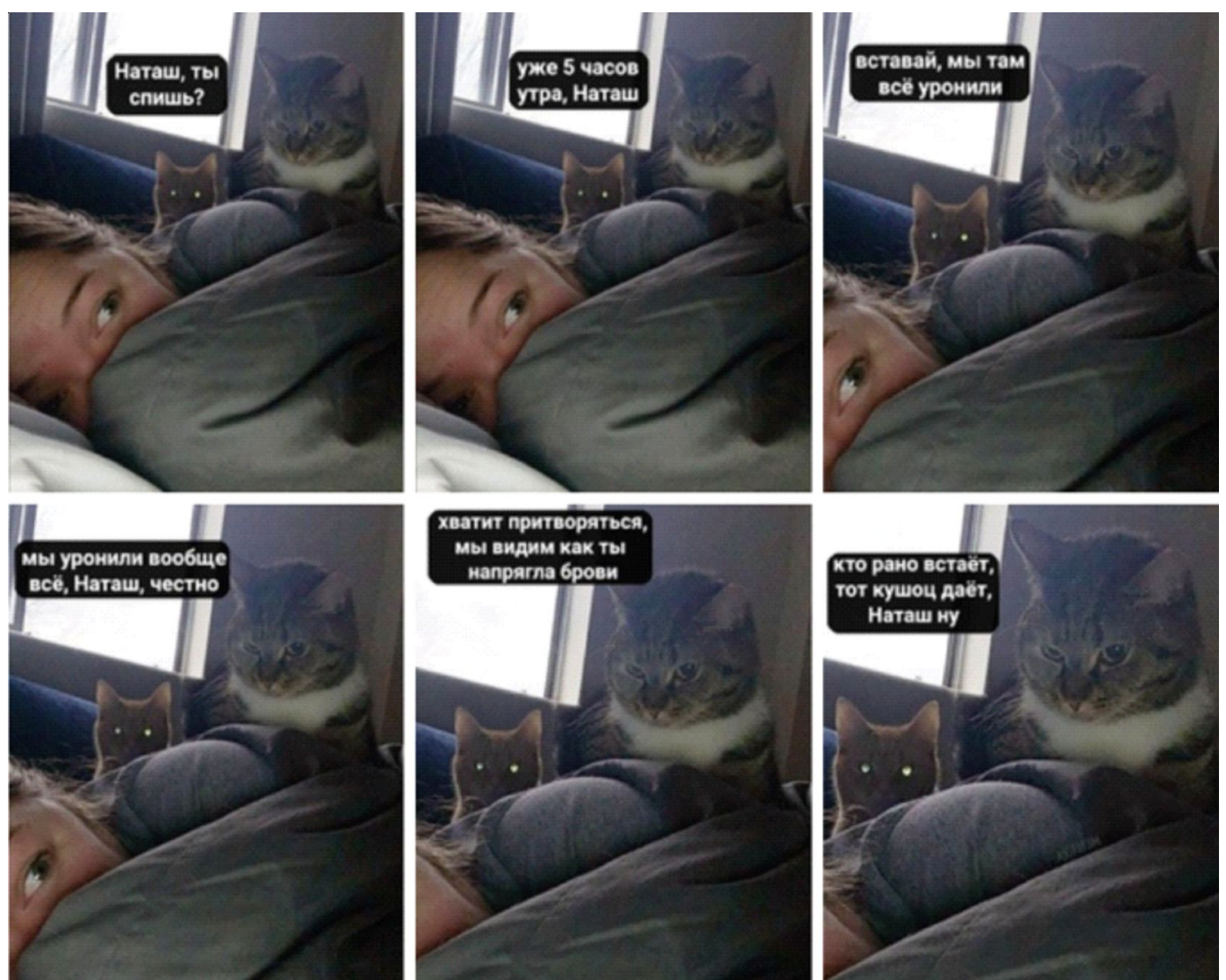

Рис. 2. Трансформация 1: развертывание фотографии в комикс

Fig. 2. Transformation 1: unfolding a photo into a comic 
У этого комикса есть визуальный прототекст: в декабре 2019 г. в паблике «Котизм» появилась фотография укрывшейся одеялом девушки и сидящими рядом с ней двумя котами. Для создания комикса авторы добавили реплики животных, усиливающие комический эффект фотографии. В первой поликодовой версии животные сообщали, что «уронили вообще все», и просили хозяйку не притворяться спящей, а покормить их. Заметим, что Наташа - не конкретное имя героини, а абстрактный персонаж, к которому нередко обращаются герои «Котизма». Ее часто можно встретить в комиксах сообщества. Таким образом, первая трансформация фотографиипрототекста происходит за счет включения вербального компонента и сюжетного развертывания: из статичного изображения адресату предлагается некий сюжет про историю с засоней-хозяйкой и ненакормленными котами. Смешная картинка могла бы остаться традиционным для интернет-коммуникации поводом улыбнуться в составе другого развлекательного контента, однако ее судьба сложилась иначе.

Шуточный комикс про то, как коты «все уронили», разошелся по соцсетям. Спустя 23 месяца появляется следующая версия мема (рис. 3).
За счет компрессии («свертки») комикс с шестью картинками превращается в одну, но визуально более выразительную: котов уже не два, а четыре (и это другие коты), и ракурс выбран такой, что они смотрят сверху вниз на хозяйку, которой в кадре нет. Взгляд котов направлен, по сути, прицельно на адресата, что усиливает во3действующий эффект. Изменился и вербальный компонент текста: «просьба» котов о том, чтобы их накормили, редуцируется на фоне неизменного призыва Вставай, мы там все уронили! Таким образом, во второй версии актуализируется семантика тревоги: произошло что-то неконтролируемое, надо срочно восстановить контроль над ситуацией. На этом этапе происходит дальнейший отрыв и от фотографии-прототекста, и от версии комикса с его конкретным бытовым контекстом, однако расширяются возможные приложения изображения к новым ситуациям.

В первые месяцы 2020 г. мем не просто сохраняет свою актуальность, но активно вовлекается в рефрейминг - изменение ситуативной рамки. Впервые в контексте новостей мем появился в конце февраля, когда произошел масштабный обвал мировых рынков из-за COVID-19. Последующим инфоповодом для рефрейминга становятся текущие события, например обвал рубля, произошедший 9 марта после обвала цен на нефть (см. рис. 4).

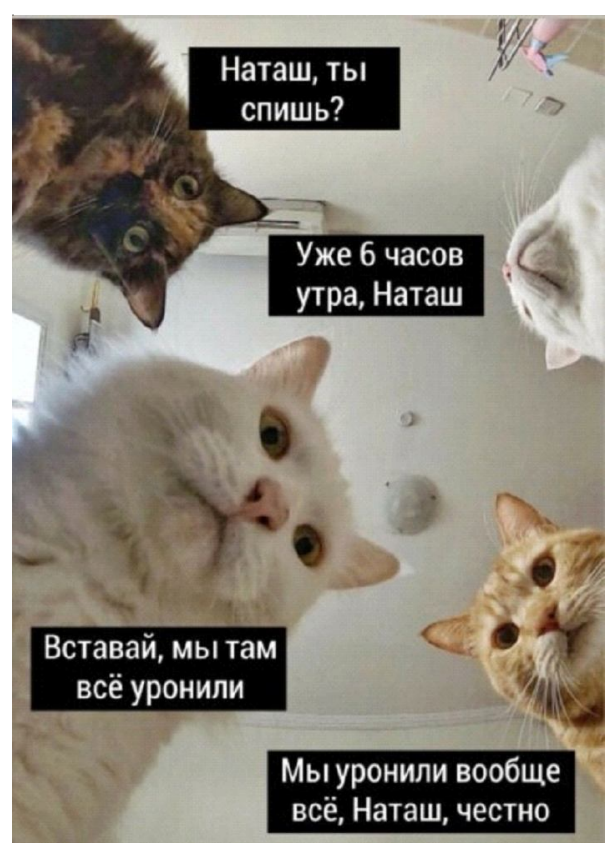

Рис. 3. Трансформация 2: «свертка»

Fig. 3. Transformation 2: "convolution" 


\section{ТЕОРЕТИЧЕСКИЕ ПРОБЛЕМЫ ИССЛЕДОВАНИЯ ТЕКСТОВ}

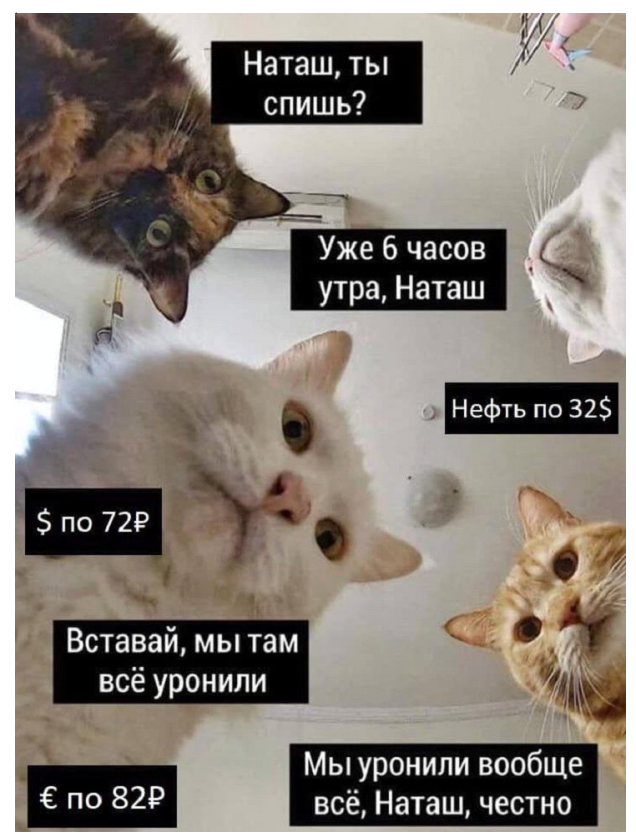

Рис. 4. Трансформация 3: рефрейминг

Fig. 4. Transformation 3: reframing

Картинка становится шаблоном для генерации новых смыслов, ориентированных на социально-политическую и экономическую ситуации. При сохранении визуального ряда в вербальный шаблон добавляются новые компоненты-реплики, отсылающие к актуальному событию. Одновременно происходит развитие метафорических смыслов ключевых реплик: $\mathrm{Mbl} в$ ве уронили употреблено уже не в прямом, а в переносном значении (уронить - 1. кого-что. к Ронять. У. платок, чашку. У. в траву. У. палатку. Уронил где-то кошелек. У. голову на подушку. У. достоинство. 2. что. Разг. Привести в упадок, расстроить (дела, хозяйство и т. п.). У. хозяйство. У. дело (Большой толковый словарь...)

9 марта 2020 г. президент В.В. Путин согласился с обнулением президентских сроков - поправкой в Конституцию, которую Госдума уже приняла вместе с остальными внесенными поправками. Картинка про котов оказалась актуальной и в этой ситуации, однако при сохранении визуального шаблона вербальный компонент трансформировался: уронили было заменено на актуальное обнулили. Отметим, что изменился и прагматический компонент текста: в отличие от прежнего призыва-побудки в связи с неприятными событиями, данное сообщение вос- принимается как позитивный повод для пробуждения (см. рис. $5, a$ ).

Изменение иллокутивной силы исходного мема наблюдается и в иной версии (см. рис. 5, б), где в контексте принимаемых правительством ограничительных мер коты призывают хозяйку к обратному действию - «не вставать»: Полежи еще, Нaташ. Не вставай. Сиди дома, там все закрыли. Примеры на рисунке 5 можно рассматривать как особую - прагматическую трансформацию мема, связанную с изменением иллокутивной силы высказывания.

В первые месяцы 2020 г. мем стал своеобразным символом информационной повестки в России: при сохранении визуального шаблона изменялся лишь вербальный компонент, однако оставалась стабильной семантика непрогнозируемого неприятного / печального результата (в случае с рублем все уронили менялось на все обвалили, с Путиным на все обнулили, с самоизоляцией - все закрыли и все самоизолировались и т. д.). Трансформационный потенциал мема, на наш взгляд, был обусловлен прагматической составляющей поликодового текста: оказалось, что изображение нетерпеливых котов - вестников тревожных событий и не слишком приятных новостей - отлично подходит и к другим ситуациям. 


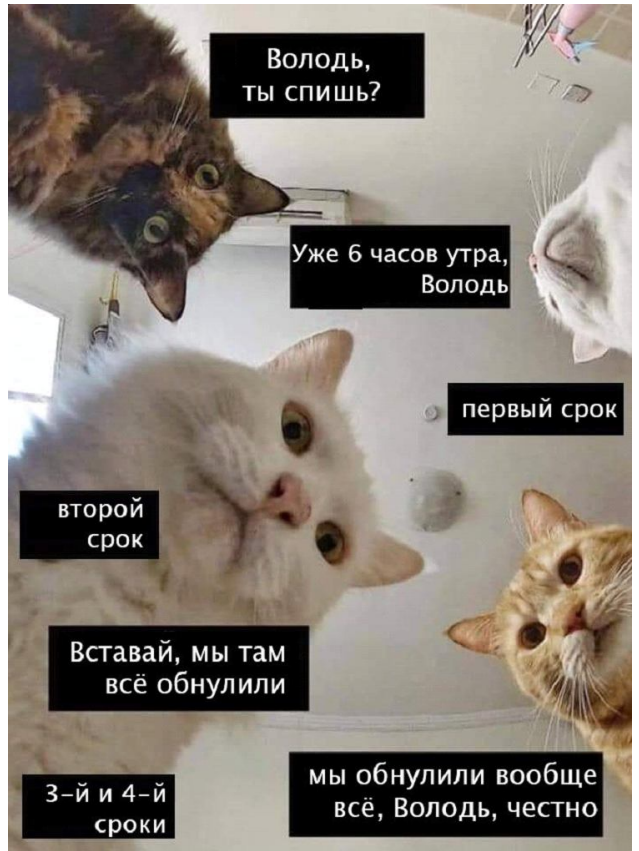

$a$

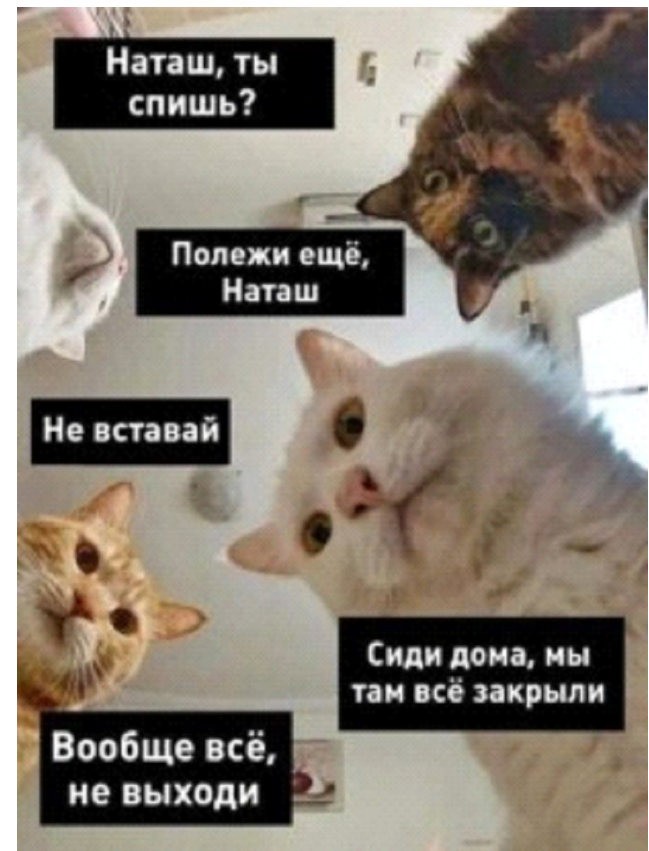

$\sigma$

Рис. 5. Прагматическая трансформация

Fig. 5. Pragmatic transformation

В апреле 2020 г. мем используется в контексте новых информационных поводов, в частности это речь президента В.В. Путина по поводу пандемии, где грядущая победа над «заразой коронавирусной» сравнивается с исторической победой над печенегами и половцами: «Наша страна не раз проходила через серьезные испытания: и печенеги ее терзали, и половцы, - со всем справилась Россия. Победим и эту заразу коронавирусную» (Владимир Путин...). Примечательно, что само президентское высказывание о врагах родины немедленно стало мемом и разошлось по сетям (см. рис. 1; по данным «Медиалогии», оно занимает 4-е место). В данном случае мы видим новую трансформацию - интертекстуальную, основанную на взаимодействии мемов, актуальных для конкретного периода (см. рис. 6, $a$ ).

Подобное взаимодействие возможно и с деактуализированными мемами - как отсылка к коммуникативным паттернам предшествующего периода. Так, слово-обращение Карл было одним из актуальных мемов 2015 года (Беженцы, санкции...). Мем использовался в серии картинок, представляющих диалог между отцом и сыном по имени Карл.
Впоследствии обращение Карл стало использоваться самостоятельно в качестве завершения фразы для выражения возмущения или просто чтобы подчеркнуть неожиданность, невероятность ситуации (Словарь языка интернета.ru, 2016, с. 51). В контексте иронического осмысления новых «мемотрендов» можно отметить метакоммуникационную трансформацию мема (см. рис. 6, б). В рамке из трех кинофрагментов использован известный мем про Карла, который вводится в актуальный контекст 2020 года. Вопрос Знаешь, что они теперь говорят вместо «Карл»? указывает на функциональную тождественность обоих феноменов творчества.

Акцент на вербальном компоненте поликодового текста обусловил такую трансформацию, как редукция визуального ряда: напоминанием о прототексте-фотографии и комиксе является только символическая фигура кота, теперь уже одного (см. рис. 7).

Следующая трансформация обнаруживает рефрейминг как вербального, так и визуального шаблона: вместо четырех котов сверху вниз на адресата смотрят полицейские (см. рис. 8). Сюжет связан с введением в апреле 2020 г. в Москве цифровых 


\section{ТЕОРЕТИЧЕСКИЕ ПРОБЛЕМЫ ИССЛЕДОВАНИЯ ТЕКСТОВ}

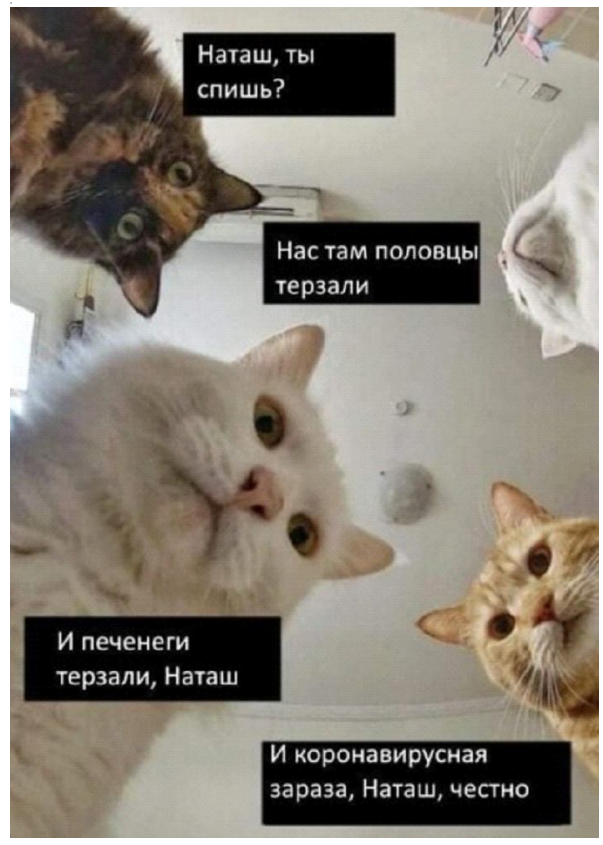

$a$

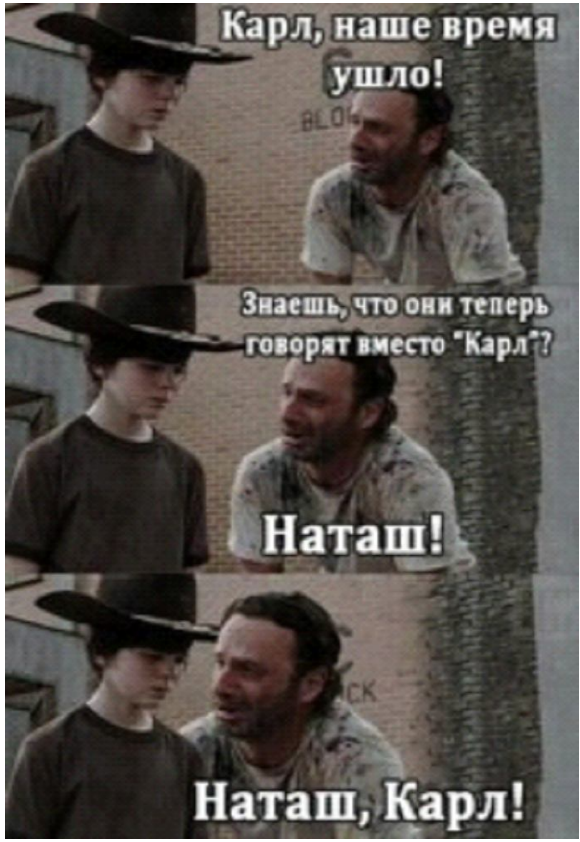

6

Рис. 6. Интертекстуальная трансформация - взаимодействие мемов и эффекты метакоммуникации Fig. 6. Intertextual transformation - meme interaction and metacommunication effects

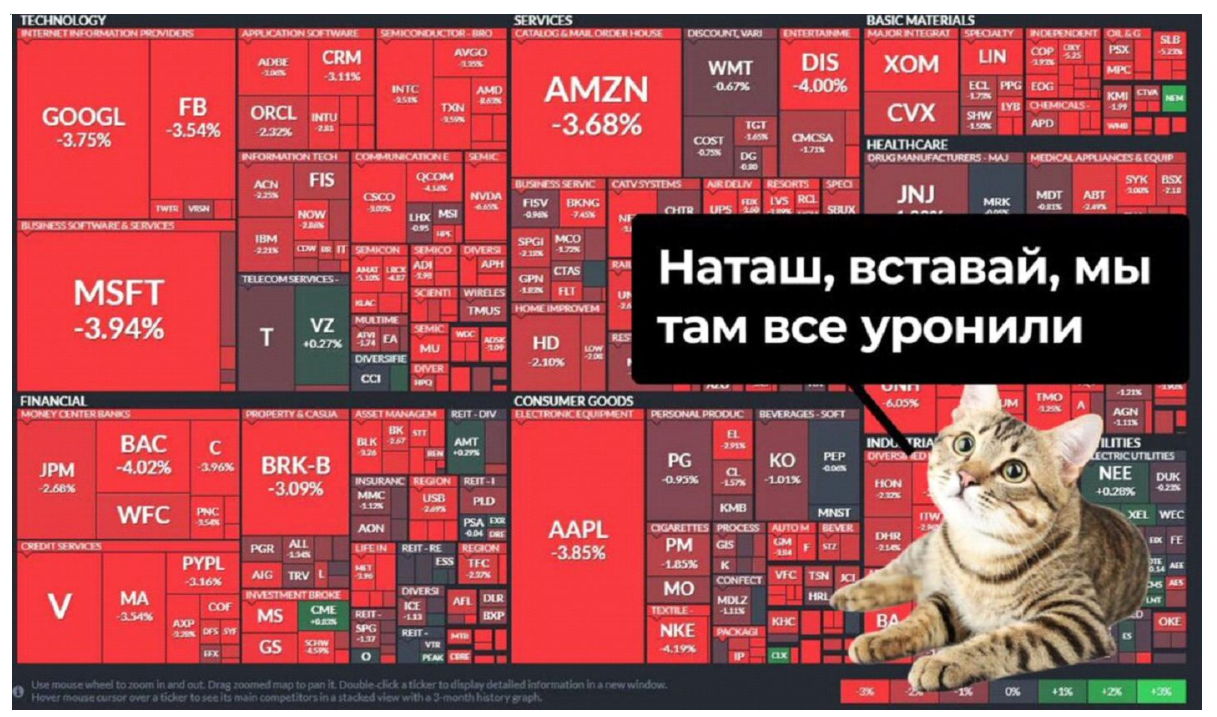

Рис. 7. Обвал фондовых рынков в «рамке» интернет-мема: редукция визуальных символов

Fig. 7. Stock market crash in the "frame" of an Internet meme: reduction of visual symbols

пропусков, которое привело к скоплению людей на станциях метро. Прагматический потенциал данного поликодового текста коррелирует с предшествующими мемами-картинками (см. рис. 3, 4), где призыв вставай/ вставайте является сигналом тревоги. Обращение к мэру Москвы С.С. Собянину имплицитно указывает на ответственного за ситуацию, что позволяет рассматривать дан- ный поликодовый текст как выражение критического отношения к столичным властям.

Таким образом, через многочисленные трансформации вербального и визуального компонентов источник мема - фотография спящей девушки с будящими ее котами - полностью изменил и свою форму, и свое содержание. Стержнем и стимулом для деривационной истории данного текста, на основе ко- 


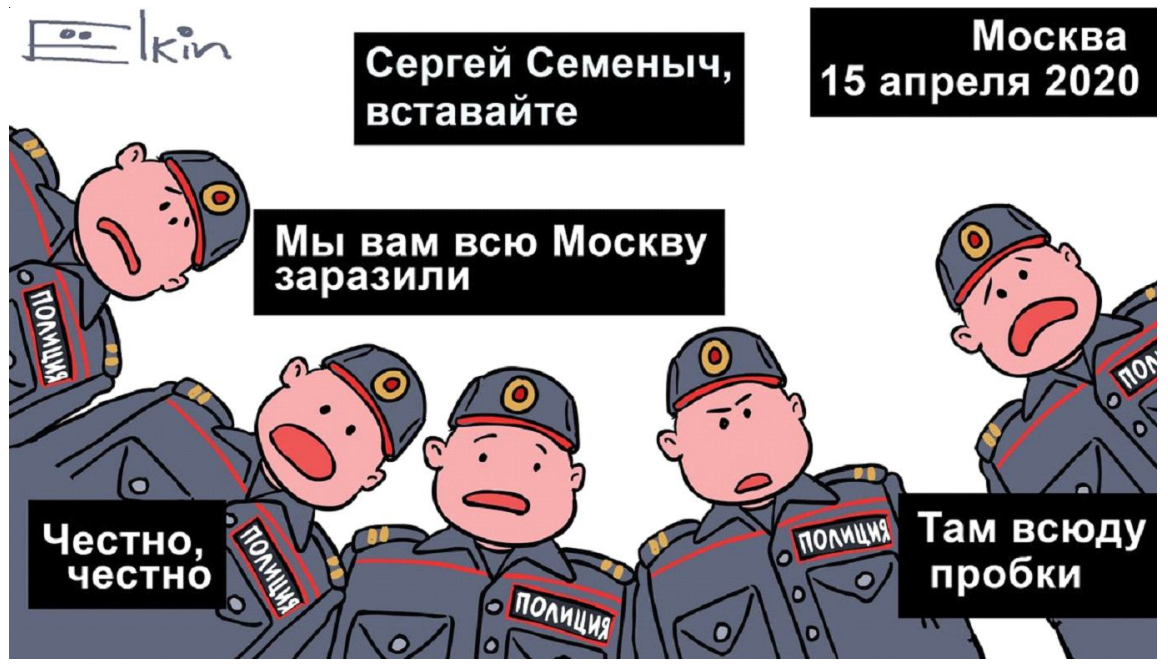

Рис. 8. Рефрейминг вербального и визуального шаблонов

Fig. 8. Reframing verbal and visual patterns

торого происходили многочисленные трансформации, стала, по сути, иллокутивная сила высказывания и визуальная рамка - ракурс.

В результате перечисленных трансформаций мем Вставай, Наташа. Mы все уронили оказался понятен и без картинок с котами, освободившись таким образом от визуальной «поддержки».

Пермская группа «НеКРОВАТЬ» исполнила песню про Наташу и котов, которые все уронили, представив, таким образом, новую, жанровую трансформацию:

Наташа, мы все уронили, вставай!

Кастрюли, цветы и немножечко рубль,

Наташа, смотри, что теперь с нами будет?

Наташа, вставай!

Bce, все вообще, все!

Все, все вообще, все!

Все-все, уронили уже.

Наташа, вставай! (https://59.ru/text/entertainment/ 69293800/)

Закономерным заключительным этапом проникновения популярного мема в медиапространство становится его появление в текстах традиционных и новых медиа, в том числе и в сильных позициях - заголовочных комплексах и лидах.

Интертекстуальные отсылки в медиатекстах представлены по-разному:

- могут включаться в заголовок и содержать фрагмент текста-источника с указанием его жанра - мема:
(1) «Наташа, мы все уронили, вообще все». Мэр Исаев велел починить набережную - ее смыло.

На этот раз больше всего досталось участку набережной под мостом. Там вообще все смыло, как в меме: «Наташа, мы все уронили, вообще все». Лестницы, асфальт, бордюры, часть песчаного пляжа, кони, люди и т. д. (https://fn-volga.ru/news/view/ id/147089);

- могут редуцироваться до ключевых слов - маркеров мема: Наташа; вставай; все уронили:

(2) Наташ, мы все уронили: мотоциклетный рынок упал за месяц... (https://www.motogonki.ru/ motonews/5-05-2020_natash_my_vse_uronili_ motocikletnyj_rynok_upal_za_mesjac_na_80-97_izza_covid-19.html);

- могут трансформироваться посредством замены отдельных ключевых слов:

(3)

a) «Новый папа»: вставай, понтифик, мы там все уронили.

Выход сериала «Молодой папа» Паоло Соррентино с Джудом Лоу в главной роли почти четыре года назад был сродни взорвавшейся бомбе. Потому что никто до созерцателя и художника Соррентино не осмеливался показать католическую церковь именно такой - без купюр, но с любовью и вниманием к деталям (https://sakhalin.info/weekly/189124);

б) «Наташ, мы там нефть уронили». Как в соцсетях отреагировали на падение цены на нефть (https://tvrain.ru/teleshow/notes/kak_v_sotssetjah otreagirovali_na_padenie_tseny_na_neft-507267/); 


\section{ТЕОРЕТИЧЕСКИЕ ПРОБЛЕМЫ ИССЛЕДОВАНИЯ ТЕКСТОВ}

в) Наташ, мы уронили еcommerce, или как помочь своему интернет-магазину взлететь (https:// vc.ru/trade/139910-natash-my-uronili-ecommerce-ilikak-pomoch-svoemu-internet-magazinu-vzletet).

При этом даже не требуется упоминания сферыисточника цитаты и оформления в кавычках прецедентного текста. Это показывает, что мем стал освоенным массовой аудиторией, вошел в современные речевые практики и опознается большинством читателей.

Следующим этапом становится использование только вербальных сигналов-триггеров, редуцирующих цитату-мем до ключевых слов: (все) уронили, вставай, Наташа. Какой срок отпущен этим «знакам текущего момента», предсказать трудно. Однако сам факт их нахождения в медийном пространстве на протяжении года позволяет говорить о концентрации в них важных смыслов, актуальных для массового сознания.

\section{Заключение}

Наблюдение за трансформациями популярного интернет-мема 2020 г. продемонстрировало одно из сущностных свойств данной поликодовой единицы - ее способность меняться на уровне формы и содержания, обеспечивая вторичный семиозис вербальных и визуальных знаков. В ходе исследования были выявлены несколько этапов трансформации исходного текста: развертывание визуального ряда в сочетании с добавлением вербального компонента; свертка визуального ряда с сохранением/ трансформацией вербального компонента; рефрейминг контекста, обеспечивающий использование мема в широком спектре актуальных ситуаций; прагматическая трансформация, приводящая к изменению иллокутивной силы высказывания; интертекстуальная трансформация, в том числе с эффектом метакоммуникации; редукция / трансформация изображения с сохранением визуальных маркеров; рефрейминг с изменением вербального и визуального компонентов; адаптация мема в текстах иных сфер и жанров.

Особую значимость имеет вхождение мема в медиатексты, причем во многих случаях - с минимальными интертекстуальными сигналами, сообщающими о связи с про- тотекстом. Это говорит об успешной адаптации интернет-мема, заимствованного из сетевого общения, к современным дискурсивным практикам массовой коммуникации.

\section{ПРИМЕЧАНИЕ}

${ }^{1}$ Исследование проведено при финансовой поддержке гранта Санкт-Петербургского государственного университета (проект № 75254082 «Моделирование коммуникативного поведения жителей российского мегаполиса в социально-речевом и прагматическом аспектах с привлечением методов искусственного интеллекта»).

The presented research was supported by Saint Petersburg State University, project № 75254082 "Modeling of Russian megapolis citizens" communicative behavior in social, speech and pragmatic aspects using artificial intelligence methods".

${ }^{2}$ В российском издании 1993 г. термин, предложенный Р. Докинзом, был переведен как «мим»; в более поздних русскоязычных публикациях, посвященных различным аспектам меметики, закрепилось написание «мем».

\section{СПИСОК ЛИТЕРАТУРЫ}

Балашова Л. В., 2020. Милитарная метафора как способ формирования концепта КОВИД-19 в речи В.В. Путина // Коммуникативные исследования. Т. 7, № 4. С. 777-800. DOI: 10.24147/ 2413-6182.2020.7(4).777-800.

Барт Р., 1989. Избранные работы : Семиотика. Поэтика. М. : Прогресс. 616 с.

Бахтин М. М., 1975. Вопросы литературы и эстетики : Исследования разных лет. М. : Худож. лит. 502 с.

Бахтин М. М., 1979. Эстетика словесного творчества / сост. С. Г. Бочаров. М. : Искусство. 423 с.

Вершинин И. На грани науки и увлечения. URL: https://sciencepop.ru/na-grani-nauki-iuvlecheniya-memetika/ (дата обращения: 08.11.2020).

Гаспаров Б. М., 1996. Язык, память, образ : Лингвистика языкового существования. М. : Новое лит. обозрение. 352 с.

Докинз Р., 1993. Эгоистичный ген. М. : Мир. Ред. лит. по биологии. $318 \mathrm{c}$.

Забалуева Е., 2018. Интернет-мем как социальное явление // Психолого-педагогическая деятельность: сферы сотрудничества и взаимодействия : материалы IV Межрегион. заоч. интернет-конф. с междунар. участием. Кострома : Изд-во Костром. гос. ун-та. С. 278-281. 
Зайцева И. П., 2020. «Коронапсихоз», «коронаскептики», «covidism», «covidophobia»и другие социолингвистические маркеры 2020 г. // Коммуникативные исследования. T. 7, № 4. C. 801-813. DOI: $10.24147 / 2413$ 6182.2020.7(4).801-813.

Кристева Ю., 2000. Бахтин, слово, диалог и роман // Французская семиотика : От структурализма к постструктурализму. М. : Прогресс. C. $427-457$.

Кронгауз М. А., 2020. Screenlife в эпоху карантина // Коммуникативные исследования. Т. 7, № 4. C. 735-744. DOI: 10.24147/2413-6182. 2020.7(4).735-744.

Ксенофонтова И. В., 2009. Специфика коммуникации в условиях анонимности: меметика, имиджборды, троллинг // Интернет и фольклор : сб. ст. / отв. ред. А. С. Каргин. М. : ГРЦРФ. С. 285-293.

Кузьмина Н. А., 1999. Интертекст и его роль в процессах эволюции поэтического языка. Екатеринбург : Изд-во Урал. ун-та ; Омск : Омский гос. ун-т. $268 \mathrm{c}$.

Куссе Х., 2020. Языковой ландшафт коронакризиса в Германии // Коммуникативные исследования. Т. 7, № 4. С. 814-845. DOI: 10.24147/24136182.2020.7(4).814-845.

Нежура Е. А. 2012. Новые типы креолизованных текстов в коммуникативном пространстве Интернета // Теория языка и межкультурная коммуникация. № 2. С. 47-52.

Радбиль Т. Б., 2020. «Самоизоляция» как новейший русский культурный концепт: когнитивнодискурсивный аспект // Коммуникативные исследования. Т. 7, № 4. С. 759-774. DOI: 10.24147/2413-6182.2020.7(4).759-774.

Савицкая Т. Е., 2013. Интернет-мемы как феномен массовой культуры // НИЦ Информкультура РГБ. URL: http://infoculture.rsl.ru/ donArch/home/KVM_archive/articles/2013/ 03/2013-03_r_kvm-s3.pdf (дата обращения: 08.11.2020).

Савченко А. В., Лай Янь-Цзюнь, 2020. «Коронавирусные неологизмы»: от лексики и фразеологии к интернет-мемам (на материале русского и китайского языков) // Коммуникативные исследования. Т. 7, № 4. С. 865-886. DOI: 10.24147/2413-6182.2020.7(4).865-886.

Северская О. И., 2020. Ковидиоты на карантикулах: коронавирусный словарь как диагностическое поле актуальных дискурсивных практик // Коммуникативные исследования. Т. 7, № 4. С. 887906. DOI: 10.24147/2413-6182.2020.7(4).887-906.

Сычев А. А. Юмор в интернет-коммуникации: социокультурный аспект. URL: http://www. abc-globe.com/sichev.htm (дата обращения: 23.10.2020).
Щурина Ю. В., 2012. Интернет-мемы как феномен интернет-коммуникации // Научный диалог. №3. C. 160-172.

Щурина Ю. В., 2013. Интернет-мем как средство межкультурной коммуникации // Известия Волгоградского государственного педагогического университета. № 6 (81). С. 34-38.

Benítez Bribiesca L., 2001. Memetics: A Dangerous Idea // Interciencia. Vol. 26 (1). P. 29-31.

Edmonds B., 2005. The Revealed Poverty of the Genmeme Analogy: Why Memetics per se Failed to Produce Substantive Results // Journal of Memetics - Evolutionary Models of Information Transmission. Vol. 9 (1). P. 1-4.

Hofstadter D. R., 1996. Metamagical Themas: Questing for the Essence of Mind and Pattern. N. Y. : Trade Paperback. 824 p.

\section{ИСТОЧНИКИ}

Беженцы, санкции и Карл вошли в ТОП «Слова года - 2015». URL: http://news.sevas.com/ world/konkurs_slovo_goda_2015_itogi (дата обращения: 08.11.2020).

Большой толковый словарь русского языка / гл. ред. С. А. Кузнецов. 1-е изд. СПб. : Норинт, 1998. URL: http:/gramota.ru/slovari/info/bts/ (дата обращения: 08.11.2020).

Владимир Путин о борьбе с коронавирусом в России. URL: https://www.interfax.ru/quotes/ 703198 (дата обращения: 08.11.2020).

Как устроена индустрия мемов и можно ли на них заработать. URL: https://style.rbc.ru/life/ 5d3b25039a794707645eld4d (дата обращения: 08.11.2020).

Лучшие мемы 2020 года. URL: https://vc.ru/social/ 192449-luchshie-memy-2020-goda (дата обращения: 08.11.2020).

Словарь языка интернета.ru / под ред. М. А. Кронгауза. М. : АСТ : ПРЕСС-КНИГА, 2016. 288 с.

\section{REFERENCES}

Balashova L.V., 2020. Militarnaya metafora kak sposob formirovaniya kontsepta KOVID-19 v rechi V.V. Putina [Military Metaphor as a Way of COVID-19 Concept Formation in the Speech of V.V. Putin]. Kommunikativnye issledovaniya [Communication Studies], vol. 7, no. 4, pp. 777-800. DOI: 10.24147/24136182.2020.7(4).777-800.

Barthes R., 1989. Izbrannye raboty: Semiotika. Poetika [Selected Works: Semiotics, Poetics]. Moscow, Progress Publ. 616 p. 
Bakhtin M.M., 1975. Voprosy literatury i estetiki: Issledovaniya raznykh let [Issues of Literature and Aesthetics: Studies of Various Years]. Moscow, Khudozhestvennaya literatura Publ. $502 \mathrm{p}$.

Bakhtin M.M., 1979. Estetika slovesnogo tvorchestva [Aesthetics of Written Word]. Moscow, Iskusstvo Publ. 423 p.

Vershinin I. Na grani nauki i uvlecheniya [On the Edge of Science and Hobby]. URL: https:// sciencepop.ru/na-grani-nauki-i-uvlecheniyamemetika/ (accessed 8 November 2020).

Gasparov B.M., 1996. Yazyk, pamyat, obraz: Lingvistika yazykovogo sushchestvovaniya [Language, Memory, Image: Linguistics of Lingual Being]. Moscow, Novoe literaturnoe obozrenie Publ. 352 p.

Dawkins R., 1993. Egoistichnyi gen [The Selfish Gene]. Moscow, Mir. Redaktsiya literatury po biologii. $318 \mathrm{p}$.

Zabalueva E., 2018. Internet-mem kak sotsialnoe yavlenie [Internet Meme as a Social Phenomenon]. Psikhologo-pedagogicheskaya deyatelnost: sfery sotrudnichestva $i$ vzaimodeistviya: materialy IV Mezhregion. zaoch. internet-konf. s mezhdunar. uchastiem [Psychological and Pedagogical Activity: Spheres of Cooperation and Interaction: Materials of the $4^{\text {th }}$ Inter-Regional Remote Internet Conference with International Contribution]. Kostroma, Izd-vo Kostromskogo gosudarstvennogo universiteta, pp. 278-281.

Zaitseva I.P., 2020. "Koronapsikhoz", "koronaskeptiki”, "covidism", “covidophobia" i drugie sotsiolingvisticheskie markery 2020 g. ["CoronaPsychosis", "Corona-Skeptics", "Covidism", "Covidophobia" and Other Sociolinguistic Markers of 2020]. Kommunikativnye issledovaniya [Communication Studies], vol. 7, no. 4, pp. 801-813. DOI: 10.24147/2413-6182. 2020.7(4).801-813.

Kristeva Yu., 2000. Bakhtin, slovo, dialog i roman [Bakhtin, Word, Dialogue and Novel]. Frantsuzskaya semiotika: Ot strukturalizma $k$ poststrukturalizmu [French Semiotics: From Structuralism to Post-Structuralism]. Moscow, Progress Publ., pp. 427-457.

Krongauz M.A., 2020. Screenlife v epokhu karantina [Screenlife in the Time of Quarantine]. Kommunikativnye issledovaniya [Communication Studies], vol. 7, no. 4, pp. 735-744. DOI: 10.24147/ 2413-6182.2020.7(4).735-744.

Ksenofontova I.V., 2009. Spetsifika kommunikatsii v usloviyakh anonimnosti: memetika, imidzhbordy, trolling [Specifics of Communication under Anonymity: Memetics, Imageboards, Trolling].
Kargin A.S., ed. Internet i folklor: sb. st. [Internet and Folklore. Collection of Articles]. Moscow, GRTsRF, pp. 285-293.

Kuzmina N.A., 1999. Intertekst i ego rol v protsessakh evolyutsii poeticheskogo yazyka [Intertext and Its Role in the Evolution Processes of the Poetic Language]. Yekaterinburg, Izd-vo Uralskogo universiteta, Omsk, Omskiy gosudarstvennyy universitet. $268 \mathrm{p}$.

Kusse H., 2020. Yazykovoi landshaft koronakrizisa v Germanii [Language Landscape of Coronacrisis in Germany]. Kommunikativnye issledovaniya [Communication Studies], vol. 7, no. 4, pp. 814845. DOI: $10.24147 / 2413-6182.2020 .7(4) .814-845$.

Nezhura E.A., 2012. Novye tipy kreolizovannykh tekstov $\mathrm{v}$ kommunikativnom prostranstve Interneta [New Types of Creolized Texts in Communicative Space of the Internet]. Teoriya yazyka $i$ mezhkulturnaya kommunikatsiya [Language Theory and Intercultural Communication], no. 2, pp. 47-52.

Radbil T.B., 2020. "Samoizolyatsiya” kak noveishii russkii kul'turnyi kontsept: kognitivno-diskursivnyi aspekt ["Self-Isolation" as the Latest Cognitive and Discursive Aspect]. Kommunikativnye issledovaniya [Communication Studies], vol. 7, no. 4, pp. 759-774. DOI: 10.24147/2413-6182. 2020.7(4).759-774.

Savitskaya T.E., 2013. Internet-memy kak fenomen massovoi kul'tury [Internet Memes as a Mass Culture Phenomenon]. NITs Informkultura RGB. URL: http://infoculture.rsl.ru/donArch/home/ KVM_archive/articles/2013/03/2013-03_r_kvms3.pdf (accessed 8 November 2020).

Savchenko A.V., Lai Yan-Jun, 2020. "Koronavirusnye neologizmy": ot leksiki i frazeologii k internetmemam (na materiale russkogo i kitaiskogo yazykov) ["Coronavirus Neologisms": From Vocabulary and Phraseology to Internet Memes (On the Materials of the Russian and Chinese Languages)]. Kommunikativnye issledovaniya [Communication Studies], vol. 7, no. 4, pp. 865886. DOI: 10.24147/2413-6182.2020.7(4).865-886.

Severskaya O.I., 2020. Kovidioty na karantikulakh: koronavirusnyi slovar' kak diagnosticheskoe pole aktual'nykh diskursivnykh praktik [Covidiots on Quaracation: Coronavirus Dictionary as an Explorative Field of Up-to Date Discursive Practices]. Kommunikativnye issledovaniya [Communication Studies], vol. 7, no. 4, pp. 887906. DOI: 10.24147/2413-6182.2020.7(4).887-906.

Sychev A.A. Yumor $v$ internet-kommunikatsii: sotsiokulturnyi aspekt [Humor in Internet Communication: Sociocultural Aspect]. URL: http://www.abc-globe.com/sichev.htm (accessed 23 October 2020). 
Shchurina Yu.V., 2012. Internet-memykak fenomen internetkommunikatsii [Internet Memes as a Phenomenon of Internet Communication]. Nauchnyi dialog [Scientific Dialogue], no. 3, pp. 160-172.

Shchurina Yu.V., 2013. Internet-mem kak sredstvo mezhkulturnoi kommunikatsii [Internet Meme as a Way of Intercultural Communication]. Izvestiya Volgogradskogo gosudarstvennogo pedagogicheskogo universiteta [Periodical of Volgograd State Pedagogical University], no. 6(81), pp. 34-38.

Benítez Bribiesca L., 2001. Memetics: A Dangerous Idea. Interciencia, vol. 26 (1), pp. 29-31.

Edmonds B., 2005. The Revealed Poverty of the GenMeme Analogy: Why Memetics per se Failed to Produce Substantive Results. Journal of Memetics - Evolutionary Models of Information Transmission, vol. 9 (1), pp.1-4.

Hofstadter D.R., 1996. Metamagical Themas: Questing for the Essence of Mind and Pattern. New York, Trade Paperback. 824 p.

\section{SOURCES}

Bezhentsy, sanktsii $i$ Karl voshli v TOP «Slova goda2015» [Refugees, Sanctions and Carl Are in the Top-List "The Word of the Year - 2015"]. URL: http://news.sevas.com/world/konkurs slovo_goda_2015_itogi (accessed 8 November 2020).

Kuznetsov S.A., ed. Bolshoi tolkovyi slovar russkogo yazyka [Big Explanatory Dictionary of the Russian Language]. Saint Petersburg, Norint Publ., 1998. URL: http:// gramota.ru/slovari/info/bts/ (accessed 8 November 2020).

Vladimir Putin o bor'be $s$ koronavirusom v Rossii [Vladimir Putin on Fight Against Coronavirus in Russia]. URL: https://www.interfax.ru/quotes/ 703198. (accessed 8 November 2020).

Kak ustroena industriya memov $i$ mozhno li na nikh zarabotat [How the Meme Industry Is Organized and If It Is Possible to Make Money on It]. URL: https://style.rbc.ru/life/ $5 \mathrm{~d} 3 \mathrm{~b} 25039 \mathrm{a} 794707645 \mathrm{e} 1 \mathrm{~d} 4 \mathrm{~d}$ (accessed 8 November 2020).

Luchshie memy 2020 goda [The Best Memes of 2020]. URL: https://vc.ru/social/192449-luchshie-memy2020-goda (accessed 8 November 2020).

Krongauz M.A., ed. Slovar yazyka interneta.ru [Dictionary of the Language of Internet.ru]. Moscow, AST Publ., PRESS-KNIGA Publ., 2016. $288 \mathrm{p}$.

\section{Information About the Author}

Oxana S. Issers, Doctor of Sciences (Philology), Professor, Dean of the Faculty of Philology and Media Communications, Head of the Department of Theoretical and Applied Linguistics, Dostoevsky Omsk State University, Prosp. Mira, 55a, 644077 Omsk, Russia, isserso@mail.ru, https://orcid.org/0000-0003-4027-6346

\section{Информация об авторе}

Оксана Сергеевна Иссерс, доктор филологических наук, профессор, декан факультета филологии и медиакоммуникаций, заведующая кафедрой теоретической и прикладной лингвистики, Омский государственный университет им. Ф.М. Достоевского, просп. Мира, 55a, 644077 г. Омск, Россия, isserso@mail.ru, https://orcid.org/0000-0003-4027-6346 